\title{
Redesigning the Education Doctorate for Community College Leaders: Generation, Transformation, and Use of Professional Knowledge and Practice
}

\author{
James E. Bartlett, II, PhD \\ North Carolina State University \\ drjamesbartlett@gmail.com
}

Michelle E. Bartlett, PhD

North Carolina State University mebartle@ncsu.edu

J. Jordan Dolfi, MLA

North Carolina State University jjdolfi@ncsu.edu

Audrey J. Jaeger, PhD

North Carolina State University

ajjaeger@ncsu.edu

Diane D. Chapman, EdD

North Carolina State University

ddchapma@ncsu.edu

\begin{abstract}
This paper describes the redesign of a community college executive leadership doctoral program that seeks to develop senior-level leaders. The paper provides how the redesign was intentionally aligned with the CPED principles and specifically the sixth principle. The paper sought data from students, faculty and other documents to gain an insight into the impact of aligning the program with principles and design concepts. The paper suggests that it is important for this program to integrate examples from practice and practitioners, include job shadowing experiences for students and faculty, and ensure there are active learning activities that are relevant to the students. The paper includes an overview of the program redesign as well as reflection on the first iteration of the new coursework through student's voice, faculty feedback, and a discussion of lessons learned.
\end{abstract}

KEYWORDS: community college leadership, education doctorate, integration of practitioners

\section{INTRODUCTION}

The redesign of the adult and community college education doctorate at North Carolina State University has been strategic and systemic to develop leaders for senior and mid-level leadership positions in North Carolina community colleges and beyond. The redesign effort applies the Carnegie Project for the Education Doctorate (CPED) guiding principles and design concepts as the core framework for the program. This program is critical to develop the next generation of community college leadership since the doctorate is often the required credential for these positions. According to the American Association of Community Colleges (AACC, 2018), there are 1,103 community colleges that served a 7.1 million student headcount as of fall 2016. The AACC Fast Facts Sheet (2018) states that $72 \%$ of community college students in 20112012 received financial aid, $36 \%$ were first-generation college students, and $53 \%$ were non-White. While it is known that community college leaders serve a large number of diverse students, creating a pipeline to supply community college executive leaders for the future has been a concern facing the profession for some time (McNair, 2010; Shults, 2001; Whissemore, 2011). Inside Higher Ed's 2017 Survey of Community College Presidents (Jaschik \& Lederman) indicated, "in 2015 , nearly one in four community colleges replaced its president" (p. 12). Another estimate suggested $50 \%$ of community college presidents will retire by 2018 (Rothwell, Gerity, \& Carraway, 2017).

The shortage of community leaders goes beyond just the president position. It is also a concern for mid- and senior-level community college positions. The AACC (2013) highlighted that the more traditional internal talent development pipeline for leaders normally included the promotion of vice presidents. However, vice presidents are also retiring at high rates. According to the results of the 2017 Survey of Community College Presidents (Jaschik \& Lederman), presidents "are divided on whether there are clear career paths to prepare for the community college presidency" (p. 12).
New articles in this journal are licensed under a Creative Commons Attribution 4.0 United States License.

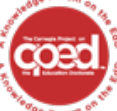

This journal is supported by the Carnegie Project on the Education Doctorate: A Knowledge Forum on the EdD (CPED) cpedinitiative.org 
Although $43 \%$ of respondents felt there were clear paths to prepare for the community college presidency, nearly the same proportion of respondents, $40 \%$, disagreed and felt there was no clear pathway to prepare future presidents. Clearly, there exists a substantial demand for community college mid- and senior-level leaders, and an education doctorate program that incorporates practice-based approaches to develop the skills and competencies needed to lead serves as part of the pathway to a presidency, as well as other leadership positions.

Even when potential leaders decide to pursue a doctoral degree, the pathway to find the specific program can be further complicated as many of these prospective students are unaware of the important distinctions between the PhD and EdD. Moreover, this situation is further convoluted when faculty members and those leading doctoral programs are often confused by the purposes of the two degrees. Over 10 years ago, Shulman, Golde, Bueschel, and Garabedian (2006) suggested, "The purposes of preparing scholars and practitioners are confused; as a result, neither is done well" ( $p$. 5). According to Perry (2012), the CPED initiative drew upon this basic premise to "Differentiate between the outcomes and expectations for doctoral candidates-those who choose to become professional practitioners $(\mathrm{EdD})$ and those who want to do research and teach in academic institutions (PhD)" (p. 44). Although both degrees have been necessary to the profession of education, it has become critical for prospective students to understand their employment goals and the knowledge, skills, and competencies needed to meet the expectations of their employers and then determine the most appropriate program to meet their needs.

\section{BACKGROUND ON THE REDESIGN OF EDUCATION DOCTORATE FOR COMMUNITY COLLEGE LEADERS}

At North Carolina State University, faculty members engaged in an extensive process of redesign to reform the Education Doctorate in Adult and Community College Education (ACCE). The redesign effort has been supported by a grant from the John M. Belk Endowment (www.jmbendowment.org). The doctoral program redesign was one of the strategies to develop this needed pipeline of mid-level and senior executive leadership for North Carolina community colleges. To develop these leaders, North Carolina State University has made a concerted effort to differentiate the goals of the EdD to provide a clear pathway that prepares practitioners to become community college leaders. The education doctorate in ACCE is housed in the department of Educational Leadership, Policy, and Human Development in the Adult, Workforce, and Continuing Professional Education program area. Although North Carolina State University offers both the $\mathrm{PhD}$ and the $\mathrm{EdD}$, the education doctorate was considered to be the most appropriate degree to redesign in order to develop practitioners for leadership positions in community colleges. This decision was supported by the work of Shulman et al. (2006) who suggested practitioners needed programs with a stronger focus on developing skills appropriate to educational practice rather than educational research.

To create a sustainable path to develop leaders, it was important to create a vision that aligns with the needs of community college stakeholders, while simultaneously meeting the needs of adult learners. These efforts were supported by creating an advisory board, which included community college presidents, community college system office executives, and thought leaders from around the nation. The program redesign effort has been part of a larger initiative entitled Envisioning Excellence for Community College Leadership, which strives to strengthen the role of North Carolina State University in outreach and engagement with community colleges including graduate education, professional development, supporting initiatives in community colleges, and research. Within Envisioning Excellence, the aim of the program narrowed the focus of the education doctorate to develop a pipeline of future leaders prepared to serve in the North Carolina Community College System.

To redesign the doctoral program, the CPED guiding principles (GPs) and CPED Design Concepts (DCs) were used in conjunction with the most current content from the field including modules based on the Aspen College Excellence Program (Wyner, 2014), Aspen Institute's Qualities of Exceptional Leaders (Aspen Institute, 2014), and national competencies for community college executive leaders such as the AACC Standards. The CPED GPs and DCs provided the foundational framework for the program redesign that delivers highly relevant content. Decisions made in the redesign process were purposefully aligned with the stakeholder needs and CPED GPs and DCs. Additionally, faculty members employed innovative educational reforms in redesigning the program, such as improvement science, to create continuous improvement. For example, student interviews provided information about version 1.0 of the redesign, which has been used to continuously improve the program design.

\section{THE PROGRAM REDESIGN}

The program includes coursework that incorporates substantial opportunities for practice and practitioners, such as practice-based dissertations that are integrated into the coursework from the start of the program and a newly designed mentoring component grounded in generating professional knowledge. To ensure the program remains student-centered and continuously improves, intentional assessment is integrated throughout the program to gather student and faculty perspectives and that information is used for program refinement. One example is the students' perceptions of community college student success. Prior to starting the program, EdD students were asked to write a definition of community college student success. The EdD students then participated in several key activities that focused on community college student success in terms of learning, completion, transfer, equity, and labor market outcomes. These activities included learning modules, interactions with professionals, and screening a film developed by the College of Southern Nevada (2015) entitled No Greater Odds that followed the story of five community college students. After these activities, data was collected that demonstrated the EdD students viewed success in a different manner. Many program participants are able to see the community college students from a larger system perspective and were able to see the end goals that included bachelor degree completion and obtaining employment with family sustainable wages.

\section{Coursework}

Coursework for the EdD program includes 14 three-credit-hour courses and 12 credit hours of dissertation research. The coursework and the sequencing were also evaluated by students and faculty members to explore opportunities to improve program outcomes. Students complete coursework in a cohort that meets in an executive format on weekends (Friday, $5 \mathrm{pm}$ to $9 \mathrm{pm}$, and 
Saturday, 8 am to $3 \mathrm{pm}$ ). Fall and spring semester courses each meet for four weekends. During the summers, students complete two courses that each meet three weekends and have one online module for each course. Students complete two courses in the summer, fall, and spring terms for two years, beginning and ending with summer terms. The last year of the program has students completing dissertation research.

The program integrates a one-credit dissertation hour into each semester of coursework, beginning in the first fall semester of the program and continuing each semester until coursework is completed. Students defend a dissertation proposal during the second year of the program. An internship course, completed in the final summer session, is another important aspect of the program that includes a reflection on the mentoring experience and completion of a project in the field.

In the program redesign, major changes to the coursework included integration of practice from the practitioner's perspective, integration of modules from the Aspen Institute, redesign of the research methods courses to meet the needs of practitioners, job shadowing, and integration of the dissertation throughout the program. The changes were designed to intentionally "emphasize the generation, transformation, and use of professional knowledge and practice" (CPED, n.d., para. 7) to improve the outcomes of students in organizations our graduates would lead.

The May 2016 cohort was the first to participate in the redesigned program and they provided data used in this paper. This redesign effort was in version 1.0 for this cohort and has continuously been improved. For example, one recent change to the program that has been implemented in the 2017 cohort is the sequence of classes. This provides an example of how program faculty members continuously monitored the program and adjusted it to improve student learning and outcomes. The 2017 cohort schedule incorporated one course designed to generate knowledge and impact practice, usually a research methods course, and one course focused on content knowledge and practice each semester. Table 1 shows that in one term, two methods courses were taught in the same term in the 2016 cohort, whereas the 2017 course structure integrated content and methods courses throughout the program with a content and methods or methods-like course being paired in each semester/summer term.

Table 1. Courses and Sequence for EdD Community College Cohort

\begin{tabular}{|c|c|c|c|c|c|c|}
\hline \multirow[t]{2}{*}{ Year/Term } & \multicolumn{2}{|c|}{$\begin{array}{l}\text { Version } 1.0 \\
\text { Cohort } 1 \text { - Location A - } 2016\end{array}$} & \multirow[t]{2}{*}{$\begin{array}{l}\text { Dissertation } \\
\text { Hours }\end{array}$} & \multicolumn{2}{|l|}{$\begin{array}{l}\text { Version } 2.0 \\
\text { Cohort } 2 \text { - Location B - } 2017\end{array}$} & \multirow[t]{2}{*}{$\begin{array}{l}\text { Dissertation } \\
\text { Hours }\end{array}$} \\
\hline & & & & $\begin{array}{l}\text { Courses to Generate } \\
\text { Knowledge and Impact Practice }\end{array}$ & $\begin{array}{l}\text { Content Courses in } \\
\text { Knowledge and Practice }\end{array}$ & \\
\hline $\begin{array}{l}\text { Year 1/ } \\
\text { Summer }\end{array}$ & Reflective Practice & The Change Process & 0 & Reflective Practice & The Change Process & 0 \\
\hline Year 1/ Fall & Leadership & Organizational Theory & 1 & Improvement Science & Organizational Theory & 1 \\
\hline $\begin{array}{l}\text { Year 1/ } \\
\text { Spring }\end{array}$ & $\begin{array}{l}\text { Research Methods } 1 \\
\text { (Quantitative) }\end{array}$ & Administrative Issues & 1 & $\begin{array}{l}\text { Proposal Writing (Integrative } \\
\text { Review of Literature) }\end{array}$ & Administrative Issues & 1 \\
\hline $\begin{array}{l}\text { Year 2/ } \\
\text { Summer }\end{array}$ & $\begin{array}{l}\text { Research Methods } 2 \\
\text { (Qualitative) }\end{array}$ & $\begin{array}{l}\text { Research Methods } 3 \\
\text { (Advanced Quantitative) }\end{array}$ & 1 & $\begin{array}{l}\text { Research Methods } 1 \\
\text { (Quantitative) }\end{array}$ & Leadership & 1 \\
\hline Year 2/ Fall & Improvement Science & Community College & 1 & Research Methods 2 (Qualitative) & Community College & 1 \\
\hline $\begin{array}{l}\text { Year 2/ } \\
\text { Spring }\end{array}$ & Program Evaluation & Workforce Development & 1 & $\begin{array}{l}\text { Research Methods } 3 \text { (Advanced } \\
\text { Quantitative) }\end{array}$ & Workforce Development & 1 \\
\hline $\begin{array}{l}\text { Year 3/ } \\
\text { Summer }\end{array}$ & Proposal Writing & Internship & 1 & Program Evaluation & Internship & 1 \\
\hline Year 3/ Fall & Dissertation Hours & - & 3 & Dissertation Hours & - & 3 \\
\hline $\begin{array}{l}\text { Year } 3 / \\
\text { Spring }\end{array}$ & Dissertation Hours & - & 3 & Dissertation Hours & - & 3 \\
\hline
\end{tabular}




\section{PURPOSE}

In this article, we provide a focused description of how CPED Guiding Principle (GP) six, which suggested redesigned EdD programs should emphasize "the generation, transformation, and use of professional knowledge and practice," (CPED , n.d., para. 7) was addressed through the redesign. In the discussion that follows, it is to be noted, that many of the CPED GPs have been interwoven and thus many of these practices were related to other principles. We describe the purpose of the program, provide an overview of courses, and discuss unique features that were designed to incorporate professional knowledge and practice into the first three courses of the redesigned program. We provide specific examples of how "the generation, transformation, and use of professional knowledge and practice" (CPED, n.d., para. 7) was woven into the first three courses of the program's curriculum. Additionally, we draw upon the voice of students to understand their perspectives on how CPED GP 6 was integrated into the program to meet their needs as leaders. This article was based on the data collected from one cohort after completion of the initial courses. The courses were EAC 711: Reflective Practice, EAC 712: Change, and EAC 704: Leadership, as well as the integrated dissertation model. The student voices were included from guided interview questions and used to examine the redesigned program from the end-user perspective. We also integrate the voices of faculty members to provide the history, context, and perceived impacts from self-reflection.

\section{THE CONTEXT FOR THE STUDY}

\section{Professional Knowledge and Practice-CPED GP 6}

The sixth CPED GP states, revised EdD programs should "Emphasize the generation, transformation, and use of professional knowledge and practice" (CPED, n.d., para. 7). In the current context, because this doctoral program was focused on the development of mid- and senior-level executive leaders in community colleges, the knowledge and practices were based on professional knowledge and practice in the context of community colleges. Community colleges have been shown to be complex organizations (Clotfelter, Ladd, Muschkin, \& Vigdor, 2013) and serve students with a wide range of needs including workforce development, associate degrees, transfer to four-year colleges, technical degrees, technical certifications, industry credentials, and continuing education. In some instances, community colleges also offer bachelor's degrees. The program is tailored to prepare practitioners specifically for the demands of this unique and complex educational environment. Therefore, the standards used for practice were drawn from the current Competencies for Community College Leaders (AACC, 2013), Crisis and Opportunity: Aligning the Community College Presidency with Student Success (Aspen Institute \& Achieving the Dream, 2013), and Hiring Exceptional Community College Presidents: Tools for Hiring Leaders (Aspen Institute, 2014a). Curriculum modules, based on lessons from the Aspen Prize from the Community College Excellence Program (Aspen Institute, 2014b), were developed to advance the skill sets necessary to undertake scaled institutional reform, tapping into leading-edge practices in areas such as change management, guided pathways, intrusive advising, and partnering with employers and other educational organizations through collective impact strategies

Additionally, the program has an emphasis on the development of leaders that are student-success driven. Student success has been assessed in several ways including high absolute performance in learning, completion, labor market, and equity outcomes. Further, the program emphasizes how important it was for leaders to create a culture that supports continuous improvement over time and the use of evidence-based practices. Although these resources provided a basis for how to transform and use professional knowledge and practice with students, with an emphasis on improvement, the students needed to develop skills with respect to generating professional knowledge and practices. This skill development was achieved in the activities and requirements of the courses.

\section{Contexts for the Three Courses}

With respect to context, we have provided details about the implementation of the courses to ensure those are clear so that the results may be readily understood by the reader. For the three courses, we provide some details that establish the context for each.

\section{Context information on Reflective Practice course} leading up to the interviews on user-centered problems of practice (PoP). Reflective Practice, the first course offered to the cohort, incorporated a project in which student groups interviewed community college practitioners, leaders, students, faculty members, and alumni about problems affecting student success on their campuses. These problems provided a base from which students considered the types of problems they might endeavor to solve in their research efforts while meeting requirements for the dissertation. In addition to traditional interviews, the instructor organized and led several online collaborative panel sessions. The panels included practitioners, community college presidents, senior level leaders, system office staff, foundation personnel, parents, and students to create a user-centered approach to identify problems facing the field.

The course included an in-class exercise using a Design Thinking approach based on the four measures (Figure 1) to student success including learning, completion/transfer, equity, labor market, as well as, organizational culture and technology. In this activity, students independently generated problems of practice they had encountered or of which they were aware. Students recorded the issues on sticky notes, then discussed and combined/condensed these into themes by group, and then again as a whole class. This preparatory work exposed students to aspects of community colleges which they might not have been aware because of their individual professional practice work. It also served as a jumping off point for the independent interviews and the online sessions that integrated practitioners. The goal of the project was to generate ideas and conversation about the problems community college practitioners currently face on their campuses to generate topics and research areas for EdD research and subsequent dissertation work to address problems of practice. 


\section{Four Measures of Community College Excellence}

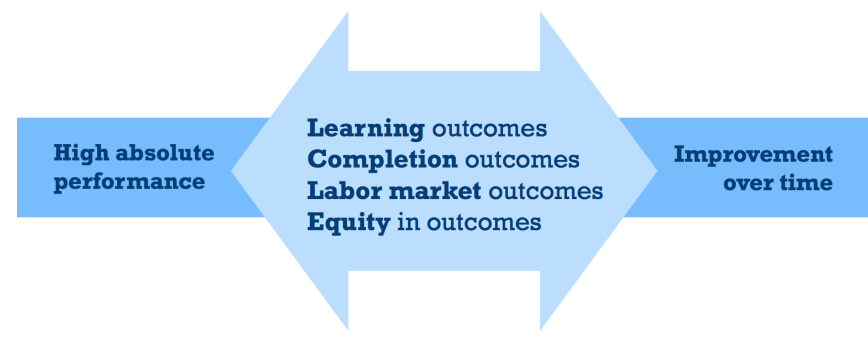

Figure 1. Aspen Institute's Model for the Measures of Community College Excellence (2014b)

\section{Context information on the Change Process course leading up to the interviews on integrating practitioners into teaching. A somewhat unique part of the program was the integration of practitioners into the classroom as instructors. They also serve as dissertation committee members. Although not every course is team taught, in the redesign version 1.0, over half of the} courses had a community college practitioner teaching in collaboration with a North Carolina State faculty member who served as the instructor of record. The second course for the cohort, entitled The Change Process, was offered in summer 2016 and co-taught by a North Carolina State professor and an Illinois community college president. The change course was situated early in the program because it included content critical for developing the skills of an executive leader and provided knowledge to understand how a dissertation can support a change effort. Further, the skills learned were foundational for future courses, which required students to implement course concepts into practice. Having the change course co-taught by a scholar and a practitioner built upon the momentum of the first course demonstrating the strong commitment to practice and the CPED principles. Other CPED programs reported similar challenges as Aiken and Gerstl-Pepin (2013), stated "we developed new faculty collaborations to begin to address some of the dualisms we faced-professional knowledge and theoretical knowledge; coursework and fieldwork; theory development and problem solutions; individual scholarship and collaborative scholarship; and traditional research and action research" (p. 174).

The North Carolina State professor delivered the theory, research, and models for implementing successful and long-lasting change based on Kotter's (2012) and Kezar's (2013) work. Concurrently, the community college president applied this knowledge and theory to community college "boots-on-the-ground" reality by teaching from his own experiences as a president at two community colleges as well as his experiences in other senior staff positions. Other examples of team-teaching included the Research Methods 1 and Research Methods 3 courses, which were taught by a North Carolina State professor and the Executive Director of Institutional Research for a large urban community college.

Context on the Leadership course including intensive shadowing and mentoring. The third course, Leadership, incorporated a substantial professional experience project. All students in the cohort received an open invitation from the community college president who served as the executive expert in the Change course to engage in substantial and individualized shadowing at the community college he serves in Illinois. Nine students and two North Carolina State faculty members participated in the experience. Students who were unable to make the trip for any number of reasons-expense, time away from work-were allowed to substitute presenting at a conference, local job shadowing, or other creative and substantial projects that would meet the professional and academic goals and needs of students.

\section{Integrated Dissertation}

Up to this point, we have addressed the coursework that was related to the CPED GP 6. Additionally, the redesigned curriculum integrated dissertation hours throughout the coursework, engaging students in the active development of dissertation topics throughout the coursework. During the first course, students began to identify problems of practice that were relevant to stakeholders. At the current point in the redesign, students had the options of doing a traditional five-chapter dissertation, three journal articles, or an action research, improvement science, or evaluation dissertation.

Starting during the first fall semester, students enroll in one dissertation hour and continue this enrollment until they have completed their coursework. During the first fall semester, students are assigned to their faculty dissertation chairs and work collaboratively with the chair to build their dissertation committees. Faculty members take responsibility for teaching the one-credit dissertation courses. In this course, students set objectives and create deliverables, while the faculty member walks the students through the dissertation process. Students work collaboratively with their dissertation chairs to develop the content of the dissertation proposal. As a result of these one-credit courses, students have the first three chapters of a traditional format dissertation or the first journal article completed and the second article proposed by the end of coursework.

\section{Improvement Science}

In addition to absolute high performance, it is critical to develop leaders that seek continuous improvement over time. Because continuous improvement was such an important concept, the course on improvement science was moved to the first fall semester for future cohorts (see Table 1). The content has included modules on (a) making the work on improvement problem-specific and usercentered, (b) focusing the importance of variation in outcomes and performance, (c) understanding systems that produce current outcomes, (d) recognizing the importance of measurements to improve at scale, (e) using inquiry to drive improvement, and (f) creating and implementing networked improvement communities (Bryk, Gomez, Grunow, \& LeMahieu, 2015). Although aspects of this were taught in the reflective practice course, it was not fully integrated until students completed the improvement science course. This course uses professional knowledge to generate new knowledge and is foundational in the transformation of quality outcomes that could be continuously improved.

\section{Additional Activities that Emphasize the Generation, Transformation, and Use of Professional Knowledge and Practice}

Other assignments were integrated through courses and within classroom instruction to support the generation of professional 
knowledge and practice. Students completed a design thinking activity, created case studies, answered abbreviated cases, and conducted poster presentations. These activities provided students with opportunities to generate professional knowledge and practice. Additionally, students used knowledge from these activities to identify problems of practice for dissertations. The dissertation has come to be viewed as another way to generate professional knowledge and practice. When asked what experiences so far in the program have most contributed to the generation of professional knowledge and practice, one student offered:

The continuous access to practitioners - the panels we've had in classes, the co-teaching with practitioners, the people who have dedicated their lives to this rather than only the academics. Integrating the data, the case study, all of it comes from practice and shows us how to apply what we're learning.

\section{Communication activities and presenting data.}

Activities like panel discussions and poster presentations were integrated into the program. Additionally, other activities that required the students to communicate in concise and effective manners were integrated. For example, students completed activities that required the visualization of data in easy to understand formats. They also had to complete an elevator pitch on the importance of student success and they completed an Ignite session on a leadership topic. Finally, the analysis of case studies was used to change practices at work. Both detailed case studies and short case studies referred to as "Dear Abby's" were used in the coursework.

\section{Method}

In the next sections, we have provided information about the students and data sources for the paper.

\section{Doctoral Student Participants}

The doctoral students that provided insight for this article are part of a cohort of 24 students. This group of students started the doctoral program in 2016. Of the 24 students in the cohort, 16 $(66.7 \%)$ were female and $10(41.7 \%)$ were individuals of color. Of the $24,13(54.2 \%)$ currently work at community colleges or in career and technical education, seven $(29.2 \%)$ others work at four-year colleges and universities, and four (16.6\%) were employed in business and industry. At the time of interviews, the students had completed eight $(57.1 \%)$ of their 14 classes including courses on Reflective Practice, Change, Leadership, Organizational Theory (Organizational Behavior), Administrative Issues (HR Issues), Research Methods I (Quantitative Methods), Research Methods II (Qualitative Methods), and Research Methods III (Advanced Quantitative Methods). Additionally, the students had completed 3 $(25.0 \%)$ of the 12 credit hours toward their dissertation.

\section{Sources of Data}

To examine how the program implemented CPED GP 6, on "the generation, transformation, and use of professional knowledge and practice," data were gathered from students, faculty members, and courses. Students were interviewed by a peer about how professional practice was incorporated into the first three courses: Reflective Practice, Change, and Leadership. It is important to note that the interviewer was a peer classmate which had the potential to affect the way respondents answered because they were speaking with a peer who had participated in the same classes and, therefore, had both a level of familiarity with the interviewed subject as well as a first-hand experience in the courses and modules discussed. Faculty members for the three initial courses participated to inform the data from their perspective. Course syllabi also served as a data source.

The interview questions used to explore how courses influenced students were:

1. In the first course, Reflective Practice, did the inclusion of the module on identifying problems of practice and talking with community college leaders transform your knowledge or practice. If yes, probe how did it?

2. The second course in the program was on Change Management and was co-taught by an NC professor and a community college president. Did having a professor and practitioner co-teach so early in our program impact your view of the program's emphasis on practice? If yes, probe how did it and why did you feel this way?

3. In the third course, Leadership, one component was a professional experience with a job shadowing as an option. Did you participate in extensive job shadowing? Did this experience build on your prior coursework? If so how and why? How has this shaped your approach to current coursework? Did this impact your knowledge and practice? If yes, probe how and why?

4. In the Change course, we learned about "buy-in." In thinking about "buying into" the program, did the first three courses impact your buy-in? If yes, how and why did you see the content or sequence of the of the first three courses benefit buy-in? Please expand on the ways the content and sequence benefit buy-in. Did the inclusion of conversations with practitioners, team-teaching, and job shadowing impact this outcome? If yes probe how and why do you think they had impact?

5. Have you had any other experiences in the program that emphasized the generation, transformation, and use of professional knowledge and practice? If yes, probe what and how did they.

\section{Results}

As noted previously, we developed practices for the first three courses to integrate CPED GP 6 into those courses. Specifically, we purposely selected the practices of (a) defining user-centered problems of practice (PoP), (b) team teaching (practitioner and faculty member), and (c) intensive job shadowing, which were incorporated as critical features into the Reflective Practice, Change, and Leadership courses, respectively.

Results for Defining User-Centered PoP. There was a consensus among the interviewed students that the project in which student groups interviewed various community college personnel and the initial course as a whole was pivotal in grounding the coursework in professional practice and orienting the cohort as a community of student practitioners. Students reflected on how the exercises invited students to bring forward PoPs from their professional arenas. They noted how collaborative efforts generated more well-rounded views of community colleges. They also appreciated that the concerns/issues discussed were based on the experiences of the student practitioners. 
For example, one student maintained:

The activity where we put the sticky notes on the walls about problems of practice was really amazing - twenty-some people in the class who all have different backgrounds and a different lens, and to see how themes emerged from everyone's individual approach was cool. The diversity of problems that community colleges and universities are facing are big, and so many l'd never thought about, and this was a great way to be able to visually see all of the areas we can help improve. This project really informed the [online] sessions because in class we'd started to identify from our own student practitioner experiences the problems we see, and it was interesting to hear the presidents' perspectives on those... That was one of my favorite activities in the cohort for generating knowledge and working together and bringing in our own practitioner lives.

This quote demonstrates how obtaining "outsider" information, actual information from others who worked in community college settings, changed students' perspectives of problems in the field because they now had a better picture of the full range of issues. The integration of the "outside" information provided perspectives that might not otherwise have been readily recognized. For example, another student suggested, "It allowed me to see from different perspectives. I work at a community college, and this project gave a more well-rounded view of the problems facing community colleges instead of just the faculty view from my perspective". This type of collaborative work on establishing research by integrating a wider range of practitioners' concerns/issues demonstrates how students' perspectives were enriched and extended beyond their initial ideas. Thus, more diverse research problems were considered. A different student stated:

That project [interviews community college practitioners] in particular, the big point was don't box yourself in, be open and whittle down from there ... don't limit yourself when you're first gathering information, and don't get stuck on preconceived ideas. It did help generate ideas, which we could reflect back to once we got through the methods coursework.

Additionally, students felt the project provided an opportunity for them to get involved on their own campus in new or more extensive ways, illustrating how student practitioners integrated the knowledge generated in class directly into their professional practice. One student who was a community college dean asserted:

For the group project, I was able to talk with folks about what makes transfer students successful or what barriers they face. I ended up talking to people I work with regularly but had never talked to them about this particular topic, and we had really fruitful conversations that are still impacting our work today, a year later.

Moreover, a project in which student groups interviewed community college practitioners facilitated conversations where students were able to gain knowledge from their own personal work environments as compared to being isolated in their silos. The project provided access points for students to learn and develop a better understanding of the community college organization. For example, one workforce development professional claimed:

This project was pivotal in helping me develop a relationship with a superior within my organization and helped me develop ongoing rapport. I learned how to connect with higher-level directors and have the opportunity to hear their outlook on educational leadership and professional development. That opportunity, the requirement to have those interviews, developed a relationship.
The generation of knowledge occurred beyond the classroom projects and new knowledge was used in the students' own workplace settings. One student suggested:

That [project] was inherently applied and practical—it was grounded in theory but had us working directly with practitioners, applying our knowledge directly to problems of practice. I was even able to incorporate ideas and problems discussed as reflected in minutes from meetings of senior leaders at my own institution and look at that in a different way that I would have normally.

From the data gathered for the project, the student teams wrote research papers. From the research papers, a comprehensive framework of problems was developed that included data from all student groups. This framework served as a guide for possible dissertation research topics. The identified problems were aligned to student success, policies and practices, professional development, engagement and communications, leadership and vision, strategy and planning, teaching and learning, and data and technology.

\section{Results for Integrating Practitioners into Teaching}

Students who were interviewed stated that the inclusion of a practitioner as a co-instructor was important to their learning in the EdD program because of the expectations that will be placed upon them after graduation, which differ from those of $\mathrm{PhD}$ scholars and researchers. One student said, "The professors in our program are amazing, but they don't have the experience of walking through all these scenarios of executive leaders on a daily basis. I'd definitely advocate for more!" Students felt program faculty members were committed to the importance of practice and suggested,

[The co-instruction] emphasized that the program is invested in helping us see how this content works in a real-world setting, how most of us can use this in our day-to-day. It's putting your money where your mouth is: having the practitioner come in and illustrate how he'd use the knowledge in his daily work life.

The students felt they still received the traditional strong content from a graduate course, but with a powerful application of those ideas. Another student exemplified this point when she stated, "[The College of Education professor] did a phenomenal job of leading the instruction in a more traditional way." And then she added:

[The community college president's] voice on how he's seen these theories evolve on the ground was very enriching. I don't connect with a lot of theories but having the real voices and real stories from real cases was fantastic. It felt like a traditional graduate course plus a high performance professional training, very practitioner-based, but with the benefit of academic instruction as well.

Another student, who serves as a community college department chair, claimed:

The co-teaching with professor and practitioner was a great strength and the Change class was one of the more valuable classes I've sat through. It's frustrating to sit there and have professors talk about all these ideas and criticisms of community colleges when they haven't spent time in the trenches and having a practitioner in the classroom alleviated that. He knows what it's like to work within the reality of community colleges, he's walked in our shoes. 
These statements provided solid examples of how the knowledge learned in the courses can be used. This collaborative teaching approach incorporated field-based education directly into the classroom and provides opportunities to view how a leader in the field uses professional knowledge in practice.

\section{Results for Intensive Job Shadowing and Mentoring}

Students who were interviewed fell into two distinct camps of thought about the job shadowing and mentoring based on their experiences in these areas. The students who were able to travel to the Illinois community college for several days of customized shadowing found the assignment and experience to be an important aspect of their program of study and professional development. By comparison, students who participated in other job shadowing or conferences did not find substantial value in their experiences. This suggests that for job shadowing to be meaningful, it must be intentional, planned, and vetted by program faculty members. One student who participated in the intensive job shadowing in Illinois stated:

[This] was one of the more important experiences l've had in the program. I wanted to get that cutting-edge feedback that I don't necessarily have at work. The experience of shadowing a sitting president and having access to his staff was more access than I have at my own institution. The experience of a multi-day immersion with a college president at an outside institution should be required.

Further, students suggested that opportunities which came from a real-world experience were not able to be simulated in the classroom. Specifically, one student claimed:

I think it's important in this kind of program to have a lot of onthe-ground education. An opportunity to meet people who are working in executive leadership positions and how they do their day-to-day, what their expectations are, how they interact with people and make decisions, so important. It was very eye opening to see him in his element-how busy he is, all the meetings and demands. I've worked for four presidents over my deanship, but never seen that work up close like I did during the shadowing. I was thrilled when the invitation was extended because it's been more guarded at my home institution. It's one thing to read about or even talk to the leader about it, but another learning experience altogether to see him in his element, how he handles things, who he's chosen to be his closest advisors. I can't imagine having a program like this without having the benefit of interaction with executive leaders.

One of the students did not participate in intensive job shadowing in the leadership course and instead presented at a professional conference. This same student later was able to attend the community college for a shadowing experience. The student stated:

For [the] Leadership [course], I presented at a conference, which is a great benefit to us in this program-it's great experience and a resume builder and ties in our academic work with our professional development. It's a great option for people who couldn't make the trip [to the community college], but what I got out of it was very different than the [intensive] shadowing I was able to do in the Administrative Issues course. Each person who visited [the community college] got a several day personally-tailored agenda based on individual interests. I traveled with another classmate who had very different interests than me, and so we had very different agendas because each was customized-what does this individual need from this experience? It wasn't cookie cutter like every student who comes is going to meet with these eight people, it was completely about what do [sic] I need to be successful in my area of research and interest.

Students who participated in other professional experiences such as presenting at a conference or local job shadowing did not find the experience to be as beneficial as those who participated in the intensive job shadowing with the practitioner associated with the program, and even had negative views of job shadowing. One student asserted, "The presentation aspect was helpful for practicing professional development-the practice of putting together a presentation or a proposal was helpful. I'm not a fan of job shadowing - it feels childish." Another student reflected, "I didn't go to [the intensive job shadowing], but I shadowed someone in the state office. It didn't really contribute [to my development] because I have so much experience in leadership. It really felt juvenile." Another student claimed, "For the intensive project in the Leadership course, I used an existing off-campus conference experience due to my calendar constraints. With more time or planning, this could have been more meaningful." Although the job shadowing experience did take a considerable amount of time and financial resources, generally students' responses support the job shadowing experience in this program as being a meaningful activity that transformed their perspectives.

Faculty members from the first two courses also participated in the job shadowing opportunity with the community college president. This provided faculty members with a realistic view of the duties of a president and offered insights into another state's community college system. The faculty members felt this was an experience in which all faculty members who were teaching in the program should participate. Further, they suggested it would be valuable to visit other schools such as those that have been Aspen finalists to learn firsthand what excellent community colleges are doing to bring examples back to the classroom.

One student spoke about how the classes have prepared students to transform professional knowledge to practice when she said:

The case study approach is helpful-a way to emulate the experience of teaching with the practitioner and professor when that isn't an option for the course. The modules where we're forced to be concise in our communication are helpful because this is the reality in the community college worldconcise presentations will be what's expected for different audiences, like the elevator pitch project, or the Ignite presentations - it forced us to synthesize and be succinct in the message-much more effective than droning on and really speaks to the practical approach of the program.

The faculty and practitioners teaching in the program both reported liking the "Dear Abby Letters" as a way to generate conversations on topics without taking a lot of time.

\section{Recommendations}

From this paper, three major recommendations emerged for doctoral programs that are seeking to develop executive community college leaders. The integration of faculty members and practitioners transformed the students' view of doctoral education. Thus, other programs may wish to consider how they may might apply integration practices of this type. If funding is limited, options exist for practitioners to participate via video conferencing, webinars, 
online video, or online discussions. Further, practitioners may help to create case studies and activities that can be used in the classroom.

Second, job shadowing that is organized in a planned, structured manner affects students' perceptions of senior leaders' work. This is also true of faculty members who participated in the Illinois job shadowing opportunity. EdD program leaders at other institutions may want to explore the benefits for both students and faculty of participating in an extensive job shadowing or internship experience.

Finally, results from these student interviews show it is important to have active learning exercises that are based on practice integrated into $\mathrm{EdD}$ programs that prepare future community college leaders. These activities include Ignite presentations, elevator speeches, case studies, "Dear Abby Letters" (short case studies), and design thinking activities. Students are more engaged when they see how material can be immediately applied to their daily practice. These types of exercises provided students with opportunities to solve problems, learn from others, and develop knowledge that can be used in their workplaces.

\section{SUMMARY}

To assist in answering the call for a pipeline for leaders at community colleges, North Carolina State University responded with the redesign of the EdD program. The completed curriculum and delivery redesign using CPED's guiding principles and design concepts was described in this article with particular attention to GP 6: "the generation, transformation, and use of professional knowledge and practice" (CPED, n.d.). Initial responses from students regarding newly incorporated classroom activities, professional experiences, and the incorporation of practitioners as guest speakers and instructors has been constructive. By continuing to obtain feedback from students, it is possible for faculty to examine students' perspectives and assess transformation of professional knowledge and practice. The program has made significant changes with the admission of each new cohort to ensure that practitioners' needs are being addressed and that the program is integrating realworld practice from multiple activities and perspectives including cases, external involvement, and current leaders. EdD program faculty are currently conducting an evaluation of the program that will be used to develop an assessment process to control quality, allow for continuous improvement and develop measures to assess the effective outcomes of the program. Currently, a study is being conducted to assess the EdD students' perceptions of the desired outcomes of the program which will allow student voice to be included in the program evaluation. The assessment of the impact of the program on learning, completion, equity, and labor market outcomes of the students is also needed as students start to complete the redesigned program. Further, assessment is being created to determine the longer-term impacts of how graduates are impacting the success of the community college students and the other stakeholders they serve and how graduates are making "a positive difference in the lives of individuals, families, organizations, and communities" (CPED, n.d.). Lastly, the improvement science model is being used to develop practices to improve the outcomes of the program. The program will continuously seek to improve and make changes to serve the stakeholders and obtain the desired outcomes.

\section{REFERENCES}

Aiken, J. A., \& Gerstl-Pepin, C. I. (2013). Envisioning the EdD and PhD as a partnership for change. Planning and Changing: An Educational Leadership and Policy Journal, 44(3/4), 162-180.

American Association of Community Colleges. (2013). AACC Competencies for Community College Leaders (2nd ed.). AACC Leadership Suite. Retrieved from http://www.aacc.nche.edu/newsevents/Events/leadershipsuite/Document

AACC_Core_Competencies_web.pdf

American Association of Community Colleges. (2018). AACC Fast Facts Sheet. Retrieved from https://www.aacc.nche.edu/research-trends/fastfacts/aacc-2018-fact-sheet-front/

Aspen Institute and Achieving the Dream. (2013). Crisis and opportunity Aligning the community college presidency with student success. Retrieved from

https://assets.aspeninstitute.org/content/uploads/files/content/docs/pubs/ CEP_Final_Report.pdf

Aspen Institute. (2014a). Hiring exceptional community college presidents: Tools for hiring leaders who advance student access and success. Retrieved from

https://assets.aspeninstitute.org/content/uploads/files/content/docs/pubs/ Hiring\%20Tools,\%20Full\%20Report,\%20FINAL.pdf

Aspen Institute. (2014b). Lessons from the Aspen prize for community college excellence. Retrieved from

https://assets.aspeninstitute.org/content/uploads/files/content/docs/ccpriz e/LessonsfromtheAspenPrizePDF.pdf

Bryk, A. S., Gomez, L. M., Grunow, A., \& LeMahieu, P. G. (2015). Learning to improve: How America's schools can get better at getting better. Cambridge, MA: Harvard Education Press.

Carnegie Project on the Education Doctorate (n.d.). About us. Retrieved from https://www.cpedinitiative.org/general/custom.asp?page=AboutUs

Clotfelter, C. T., Ladd, H. F., Muschkin, C. G., \& Vigdor, J. L. (2013). Success in community college: Do institutions differ? Research in Higher Education, 54(7), 805-824.

Inside Higher Ed \& Gallup (2017). 2017 Community College Survey. Washington, DC: Author. Retrieved from https://www.ellucian.com/WhitePapers/2017-Survey-Community-College-Presidents/

Jaschik, S., \& Lederman, D. (2017). Inside Higher Ed's 2017 survey of community college presidents: A study by Inside Higher Ed and Gallup. Retrieved from https://www.insidehighered.com/news/survey/communitycollege-presidents-surveyed-enrollment-recruitment-pipeline

Kezar, A. (2013). How colleges change: Understanding, leading, and enacting change. New York, NY: Routledge.

Kotter, J. P. (2012). Leading change. Boston, MA: Harvard Business Review Press.

McNair, D. E. (2010). Preparing community college leaders: The AACC core competencies for effective leadership \& doctoral education. Community College Journal of Research and Practice, 33(1-2), 199-217.

Perry, J. A. (2012). To EdD or not to EdD? Phi Delta Kappa, 94(1), 41-44.

Rothwell, W. J., Gerity, P. E., \& Carraway, V. L. (2017). Community college leaders on workforce development: Opinions, observations, and future directions. Lanham, MD: Rowman \& Littlefield.

Shulman, L. S., Golde, C. M., Bueschel, A. C., and Garabedian, K. J. (2006) Reclaiming education's doctorates: A critique and a proposal. Educational Researcher, 35(3), 25-32. Retrieved from http://journals.sagepub.com/doi/pdf/10.3102/0013189X035003025

Shults, C. (2001). The critical impact of impending retirements on community college leadership (Leadership Series No. 1). Washington, DC: American Association of Community Colleges.

Whissemore, T. (2011, December 6). Bridging the leadership gap. Community College Daily. Retrieved from http://www.communitycollegetimes.com/Pages/CampusIssues/Bridging-the-leadership-gap.aspx 